Lutkovskyi Ruslan. Evaluation of the effectiveness using nanomodified polipropilene meshes at laparoscopic operations of a hernia of a stomach. Journal of Education, Health and Sport. 2020;10(7):343-349. eISSN 2391-8306. DOI http://dx.doi.org/10.12775/JEHS.2020.10.07.036

https://apcz.umk.pl/czasopisma/index.php/JEHS/article/view/JEHS.2020.10.07.036

https://zenodo.org/record/4068544

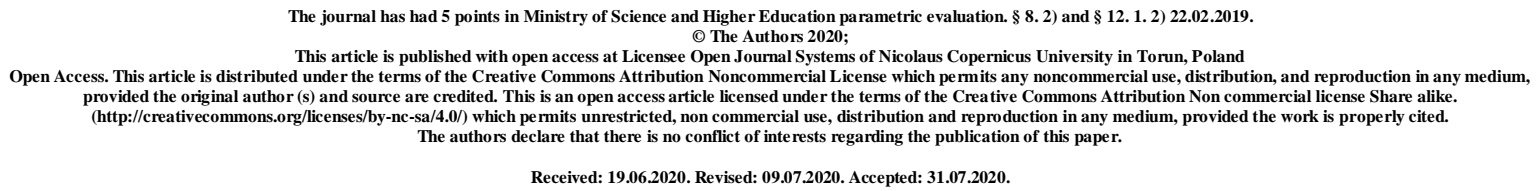

UDK: 617.55-007.43-089-06:539.55

\title{
Evaluation of the effectiveness using nanomodified polipropilene meshes at laparoscopic
} operations of a hernia of a stomach

\section{Ruslan Lutkovskyi}

\section{Vinnitsa National Pirogov Memorial Medical University, Ukraine Ph.D., Associate Professor, Department of General Surgery}

\begin{abstract}
In laparoscopic surgical treatment of incisional abdominal hernia (AH) of great sizes, using polypropylene mesh, buth this is accompanied by a fairly high freguency of postoperative complications from the postoperative wound.

In our view, the use of a polypropylene mesh modified by carbon nanotubes and an antiseptic of polyhexamethleneguanidme chloride the results of surgical treatment of AH.

Aim - to improve the results of laparoscopic surgical treatment of incisional abdominal hernias of great proportions by using in combination with nanomodified polypropylene mesh.

Materials and methods. The analysis of laparoscopic surgical treatment of 240 patients with $\mathrm{AH}$ of great sizes has been performed. Depending on the type of mesh used during laparoscopic surgical treatment, patients were divided into 2 groups. In 120 (50\%) of Group I patients, the component aloplasty with the use of a nanomodified polypropylene mesh. In the 2nd group, $120(50 \%)$ patients used the aloplasty with the use of a classic polypropylene mesh.
\end{abstract}


Results and discussion. Statistically significant results were obtained in patients of Group I compared to Group II: seroma was in $17(7.0 \pm 1.2 \%)$ in Group II compared to 4 $(1.8 \pm 0.3 \%)$ in Group I $(\mathrm{p}<0.05)$. Chronic pain in the abdominal wall in $6-8$ months after surgery was observed in $13(5.3 \pm 0.4) \%$ patients in group II and in 0 group I (p>0.05), recurrences of hernia were found in $13(5.3 \pm 0.4 \%)$ patients of group II, in group I - in 4 $(1.8 \pm 0.6) \%(\mathrm{p}<0.05)$. The terms of stay of patients of group II on inpatient treatment $5,3 \pm 2,1$ days group $\mathrm{I}-2,1 \pm 1,2$ days.

Conclusion. Laparoscopic operacione treatment of UH using nanomodified polypropylene mesh antiseptic the use of the classical polypropylene mesh, namely, reducing the freguency of seroma from $7.0 \pm 1.2 \%$ in the II group of patients to $1.8 \pm 0.3 \%$ in group I, chronic postoperative pain - from $5.3 \pm 0.4 \%$ to 0 , recurrence of hernia-from $5.3 \pm 0.4 \%$ to $1.8 \pm 0.6 \%$.

Key words: abdominal hernia; nanomodified polypropylene mesh; postoperative wound complications.

Introduction. Anterior abdominal wall hernias and umbilical hernia (UH) in particular are a leading surgical pathology which needs planned operative interferences. Operations on UH are in the third place among hernia defect's plasty. Despite the fast development of modern herniology, the problem of UH surgical treatment remains actual. The problem is that every tenth patient after surgical treatment of simple uncomplicated umbilical hernia has got the relapse, and after the treatment of a larger in size hernia - even more often. According to Pheleshtinskii (2011), the frequency of the relapse still remains very high from 30 to $35 \%$. Foreign and domestic authors suggest using a "tension-free" technology (plasty without tension) with the materials that are at most adapted to the organism's tissues and do not produce allergens, are able to resist the mechanical act at the junction of tissues and affordable in price. But it is worth noting, that using a classical polypropylene mesh during the operation leads to the high complication rate from the side of post-operative wounds, such as seroma $(30.8-60.4 \%)$, the purulence of post-operative wound $(4.8-6.4 \%)$, ligature fistules $(1.2-3.0 \%)$, meshoma $(0.06-1.60 \%)$. One of the reasons of post-operative wounds complications is a development of anterior abdominal wall tissues aseptic inflammation, as a result of their contact with the classical polypropylene mesh. A long-term aseptic inflammation of subcutaneous base, muscles, aponeurosis and fascia slows down the process of polypropylene mesh's germination with the connective tissue, which leads to its corrugation, and in case of infection's joining - to the mesh migration and hernia relapse. In 
our opinion, using the nanomodified propylene mesh with the antiseptic will give an opportunity to improve the results of UH operative treatment.

Purpose of the work is to improve the results of abdominal hernias' laparoscopic surgical treatment using the nanomodified polypropylene mesh with antiseptic.

\section{Materials and methods}

There was analysed the laparoscopic surgical treatment of 114 patients aged from 35 to 70 in the period from 2014 to 2019 . They have been diagnosed with umbilical hernia and undergone the laparoscopic operation with further deployment and fixation of meshy implants. Other 126 examined patients have got white line's hernia combined with rectus abdominis muscle's diastasis and undergone the laparoscopic operation with retromuscular placement of meshy implant. Generally, the laparoscopic surgical treatment of 240 patients was analysed. Concomitant diseases with the prevalence of chronic cardiovascular pathology were revealed at $75(31.1 \%)$ patients, the obesity of II-III stage - at $126(52.4 \%)$, the chronic bronchitis - at $9(3.7 \%)$, diabetes - at 19 (7.9\%), chronic venous failure of lower extremities at $11(4.9 \%)$.

The special preoperative preparation on an outpatient-basis was given to all patients during $(10,0 \pm 3,4)$ days, which comprised: 1$)$ the adaptation of cardiovascular and respiratory systems to the raising of intracranial pressure, 2) raising the reserves from the side of cardiopulmonary activity, 3) correction therapy of concomitant diseases, 4) prophylaxis of thromboembolic complications, 5) prophylaxis of infectious complications of postoperative wounds, 6) utter bowel's cleansing. For the cleansing of bowel and decreasing its volume the slag-free diet with the elimination of bread, flour and potato dishes was recommended to the patients and laxatives ("Regulax", "Dufalac") and cleansing enemas were prescribed. In this way it is possible to achieve the complete bowel's cleansing, decreasing its volume and hernia's protrusion and also decreasing the patient's bodyweight. The abdomen's circumference decreases on average, $14-16 \mathrm{~cm}$, and some patient's irreducible hernias became reducible. "Fortrans" was prescribed according to the 12-hours scheme before the operative intervention.

The adaptation of respiratory and cardiovascular system to the increased intracranial pressure was carrying out with the help of dosed bandage abdomen's compression and a special complex of respiratory gymnastics. The abdomen was dosed compressed with the focus on the patient's well-being. The bandage compression was carrying out only on patients with reducible hernias, because with the case of irreducible hernias it can lead to pinching. 
The efficiency of preoperative preparation was controlled by means of cardiovascular and external breathing functions' monitoring. Antibacterial prophylaxis was carried out using the third-generation cephalosporin (Cephosulbin) 2 hours before the operation. With the aim of thromboembolic complications prophylaxis "Clexane" dosed $40 \mathrm{mg}$ was used subcutaneously 12 hours before the operation and once per day after the operation during 7 9 days as well as the compressional underwear to lower extremities during the operation and within a month in the postoperative period.

Depending on the type of meshy implant used during the laparoscopic surgical treatment of abdomen hernias, patients were divided into two groups and compared by the age, sex correlation and size of abdomen hernia, 120 patients $(50 \%)$ of the first group underwent the abdominal hernia's operation using the nanomodified propylene mesh with antiseptic, 120 patients (50\%) of the second group underwent the abdominal hernia's operation using the classical propylene mesh.

During the early postoperative period therapeutic measures included disturbances correction of cardiovascular and respiratory systems, bowel's function stimulation. "Dicloberl" dosed $3 \mathrm{ml}$ was prescribed to use intramuscularly to all patients for 7 days for abdominal wall's inflammation reaction on the mesh implanting decreasing. With the aim of the gastrointestinal tract's stress ulcer's prophylaxis "Quamatel” was prescribed according to the scheme. Antibacterial therapy, including Cephosulbin 1g twice per day, was continued, as all of them had the increased risk of the wound infectious complications occurrence. Thromboembolic complications prophylaxis was carrying out with "Clexane" dosed $40 \mathrm{mg}$ during $7-9$ days.

For the statistical calculations the integral system STATISTICA® 5.5 (STAT+SOFT® Snc, USA), using the license program (AXX 910A374605FA) was used.

\section{Results and discussion}

The results of abdominal hernias' laparoscopic surgical treatment among the patients of I and II groups were estimating by studying and comparing the postoperative complications.

The results of laparoscopic surgical treatment. According to the statistics significantly better results were received among the patients of the group I unlike the group II $(p<0,05)$ : decreasing of seroma formation was observed from $17(7,0 \pm 1,2)$ to $4(1,8 \pm 0,3) \%$. Chronical pain in the abdominal wall's region during $6-8$ months after the operation was observed at $13(5,3 \pm 0,4) \%$ patients of the II group, which was eliminated in the way of prescribing the physiotherapeutic procedures and non-steroidal anti-inflammatory drugs unlike the group I, 
where such complications were not observed. Hernia's relapse arose among $4(1,8 \pm 0,6) \%$ patients of group I unlike the $13(5,3 \pm 0,4) \%$ patients of group II $(\mathrm{p}<0.05)$. The duration of stationary treatment in the group I took $(2,1 \pm 1,2)$ days, in the group II it took $(5,3 \pm 2,1)$ days.

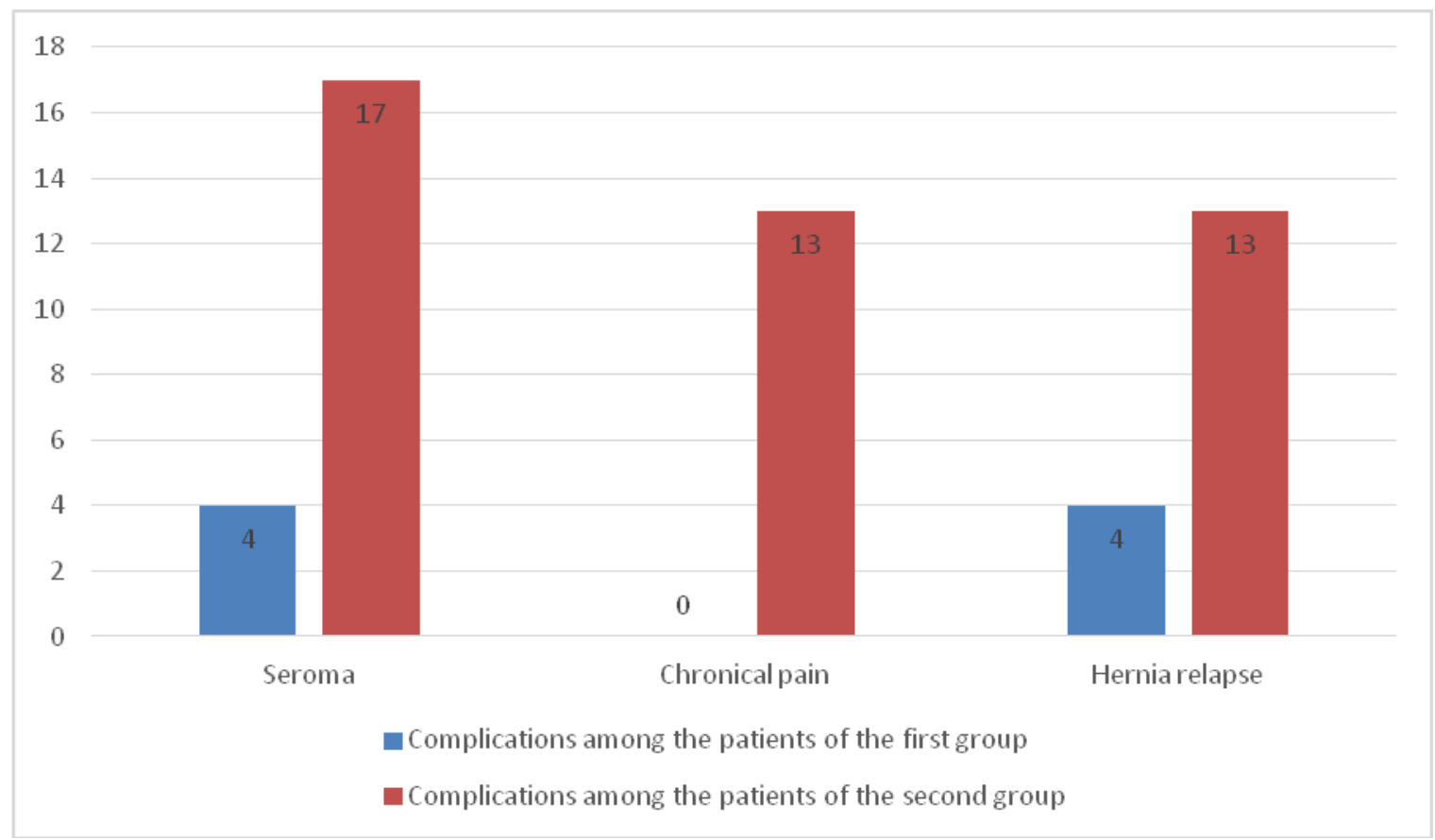

Fig. The results of the laparoscopic surgical treatment of the patients with abdominal hernias

Thereby, notably better results of laparoscopic surgical treatment were received in patients of group II. Due to nanomodified polypropylene meshy implant used for group I it was possible to achieve the reduction of seroma frequency occurrence in 4.2 times, chronical postoperative pain in 3 times and relapse's occurrence of abdominal hernia in 3 times as well. It is useful to note, that such a significant reduction of complications frequency is due to characteristics of nanomodified polypropylene mesh with the antiseptic polyhexamethylene guanidine chloride, specifically it owns the high sorption, hygroscopic and antiseptic effects whereby it helps to reduce the intensity of abdominal wall's tissues' aseptic inflammation, serous liquid's exudation and the risk of infection. Also it reduces the ability of mesh's migration and corrugation while the classic polypropylene mesh has not such aforementioned characteristics.

\section{Conclusions}

The laparoscopic surgical treatment of abdominal hernias based on the nanomodified polypropylene mesh is more effective compared to using the classical polypropylene mesh. That was proved by the reduction of seroma frequency from $(7,0 \pm 1,2)$ to $(1,8 \pm 0,3) \%$, 
chronical postoperative pain - from $(5,3 \pm 0,4)$ to 0 , hernia relapse - from $(5,3 \pm 0,4)$ to $(1,8 \pm 0,6) \%$.

\section{Perspectives of the further researches}

On the basis of further performed researches new approaches to the surgical treatment of abdominal hernias, using new kinds of nanocomposite meshy implants with antibacterial characteristics of domestic production will have been developed. It will allow to reduce the quantity of postoperative complications and hernias relapses and, moreover, to improve the quality of patients' life whistle the postoperative period leading to the significant economical effect.

\section{References}

1. Bendik N.I., Rucavzev G.I. (2003) Zastosuvannja vitchusnjanoi chirurgichnoi polipropilenovoi sitku [Application of domestic surgical polypropylene mesh]. Kyiv: Klinichna chirurgia, 11, 8 [in Ukrainian].

2. Lutkovskyi R.A. (2019) Operativne likuvannja pisljaoperacijnich grig givota velikogo rosmiru pri vikoristanni polipropilenovoi sitki modifikovanoi vuglezevumi nanotrubkami ta antisepticom [Surgical treatment of largesized postoperative abdominal hernias using polypropylene mesh modified with carbon nanotubes and antiseptic]. Poltava: Visnik problem biologii i medicine, 1, 167-170 [in Ukrainian].

3. Lutkovskyi R.A. (2017) Reakcija tkanin na polipropilenovi sitchasti implantati [Response of tissues to polypropylene mesh implants]. Vinnica: Visnik morfologii, 2, 295299 [in Ukrainian].

4. Lutkovskyi R.A. (2018) Morfologichnij ta morfometrichnij analis smin v tkaninach pri implantacii sitchastich implantativ $\mathrm{s}$ polipropilenu modifikovanogo vuglecevumu nanotrubkamu ta antisepticom [Morphological and morphometric analysis of tissue changes in implantation of mesh implants made of carbon nanotube modified polypropylene and antiseptic]. Vinnica: Visnik Vinnickogo nacionalnogo medichnogo universitetu, 1, 19-23 [in Ukrainian].

5. Mirsabekjan J.R., Dobrovolskij S.R. (2008) Prognos i profilactica ranevich oslognenij posle plastici perednej brjushnoj stenki po povodu posleoperacionnoj ventralnoj grigi [Prediction and prevention of wound complications after plastic surgery of the anterior abdominal wall regarding postoperative ventral]. Kyiv: Chirurgia, 1, 66-71 [in Russian].

6. Netjaga A.A., Begin A.I. (2010) Endoprotezirovanie brjuschnoj stenki v lechenii i profilactici narugnich grig givota [Endoprosthetics of the abdominal wall in the treatment and 
prevention of external abdominal sugeries]. Vinnica: Materialu XXII zizdu xirurgiv Ukraini 57-58 [in Russian].

7. Lutkovskyi RA, Feleshtynskiy JP, Viltsanuk OA, Rezanova NM, vinachidniki. Vinnuckuj nazionalnuj medichnij universitet imeni M.I.Pirogova patentovlasnik. Sposib aloplastiki pisljaoperazijnuch ventralnich grug $\mathrm{s}$ vikoristannjam nanomodifikovanoi polipropilenovoi sitku. Patent Ukrainu na korusnu model №132818. 2019 Ver 11. [inUkrainian].

8. Saenko V.F., Beljanskij L.S., Manojlo N.N. (2001) Sovremenie napravlenie otkritoj plastiki grigi brjuschnoj stenki [The modern direction of open plastic abdominal wall surgeries]. Kyiv: Klinichna chirurgia, 6, 59-63 [in Russian].

9. Feleschtinskij J.P., Smischuk V.V., Prepodobnij V.V., Malenda O.D. (2011) Vubir sposobu aloplastici pri chirurgichnomu licuvanni pupcovich grig [Choosing a method of alloplasty in the surgical treatment of umbilical hernias]. Kyiv: Chirurgia Ukraini, 3, 146-147 [in Ukrainian].

10. Feleschtinskij J.P.(2012) Pisljaoperacijni grigi givota [Postoperative abdominal hernias]. Kyiv: TOV «Bisnes-Logika» [in Ukrainian].

11. Millbourn D., Cengiz Y., Israelsson L.A. Risk factors for wound complications in midline abdominal incisions related to the size of stitches // Hernia. - 2011. - Vol. 15. - P. $261-266$.

12. Perrakis E., Velimezis G., Vezakis A. et al. A new tension-free technique for the repair of umbilical hernia, using the Prolene hernia system: early results from 48 cases // Hernia. - 2003. - № 7(4). - P. 178 - 180.

13. Sanders D.L., Kingsnorth A.N. From ancient to contemporary times: a concise history of incisional hernia repair // Hernia. - 2011. - Vol. 16. - P. 1 - 7. 